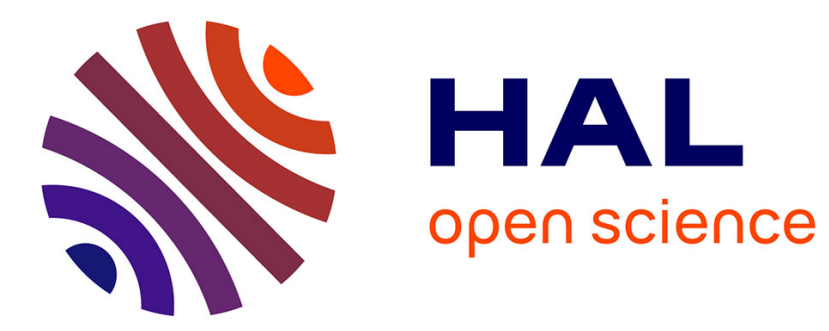

\title{
10 th of April 1987 seismic swarm: Correlation with geochemical parameters in Campi Flegrei Caldera (southern Italy)
}

\author{
Dario Tedesco, Luisa Bottiglieri, Raimondo Pece
}

\section{To cite this version:}

Dario Tedesco, Luisa Bottiglieri, Raimondo Pece. 10 th of April 1987 seismic swarm: Correlation with geochemical parameters in Campi Flegrei Caldera (southern Italy). Geophysical Research Letters, 1988, 15 (7), pp.661-664. 10.1029/GL015i007p00661 . hal-03551298

\section{HAL Id: hal-03551298 \\ https://hal.science/hal-03551298}

Submitted on 1 Feb 2022

HAL is a multi-disciplinary open access archive for the deposit and dissemination of scientific research documents, whether they are published or not. The documents may come from teaching and research institutions in France or abroad, or from public or private research centers.
L'archive ouverte pluridisciplinaire HAL, est destinée au dépôt et à la diffusion de documents scientifiques de niveau recherche, publiés ou non, émanant des établissements d'enseignement et de recherche français ou étrangers, des laboratoires publics ou privés. 


\section{0 ${ }^{\text {th }}$ OF APRIL 1987 SEISMIC SWARM: CORRELATION WITH GEOCHEMICAL PARAMETERS IN CAMPI FLEGREI CALDERA (SOUTHERN ITALY).}

1,2Dario Tedesco, ${ }^{2}$ Luisa Bottiglieri and ${ }^{3}$ Raimondo Pece

Abstract A close relationship between geophysical activity (seismicity and ground deformation) and chemical changes in volcanic reservoirs has been proposed several times in active volcanic areas. In Campi Flegrei caldera especially during the bradyseismic crisis which occurred between 1982-1984, this correlation was never clearly demonstrated because of the high rate of occurrence of earthquakes and the small number of gas samples.

After at least two years of both geochemically and geophysically quiescent period, a swarm of 50 earthquakes, felt in the area of the Solfatara crater with 2.0 maximum magnitude, occurred on the $10^{\text {th }}$ of April 1987. At about the same tume (before and after), several geochemical parameters showed important changes in concentration. These include water vapour, nitrogen, hydrogen, methane and to a lesser extent hydrogen sulfide in fumarolic gases from Bocca Grande fumarole in the Solfatara crater and the radon content in water wells situated far from the swarm epicentral area. In our opinion, the processes causing the geochemical changes are linked to aseismic creeping mechanisms, which leads to an easier rising of fluids in fumaroles $\left(\mathrm{H}_{2} \mathrm{O}, \mathrm{N}_{2}, \mathrm{H}_{2}\right.$ and $\left.\mathrm{CH}_{4}\right)$ and in the superficial water table $(\mathrm{Rn})$.

The subsequent seismicity could be related to consequent local stress accumulation on gas reservoir rocks induced by creeping.

\section{Introduction}

The Campi Flegrei caldera was formed about 35.000 years ago following the eruption of the Campanian Ignimbrite. After the caldera formation, several other eruptions occurred in the interior of the same caldera forming many eruptive monogenic centers until the last eruption recorded in historical time, the monte Nuovo eruption in 1538 [Ros1 et al., 1983; Lirer et al., 1987].

In the Campi Flegrei caldera, during the last 18 years, two different stages of bradyseismic crises have been monitored, in 1970-72 and 1982-84. The second was particularly vigorous, compared to the previous one, with rapid uplift of more than $180 \mathrm{~cm}$ in about 3 years, and several earthquakes with magnitudes greater than 4 [Barberi et al., 1984]. At the same time 40,000 people were evacuated from Pozzuoli, the main town in the region. Since 1983, the Osservatorio Vesuviano started geochemical surveillance of the area in order to detect possible variations in chemical parameters. The recorded variations may explain changes in physical parameters and thermodynamic conditions of the reservoirs feeding fumaroles and superficial waters where the samples were collected.

On the $10^{\text {th }}$ of April 1987, after more than 2 years of quiescent period, a swarm of about 50 earthquakes with a maximum magnitude of 2.0 , was recorded by the seismic network of the Osservatorio Vesuviano in an area west of the Solfatara crater [Luongo and Ricciardi, 1987] (Figure 1). At

'Centre des Faibles Radioactivités.

2Osservatorio Vesuviano Napoli.

${ }^{3}$ Dipartimento di Geofisica e Vulcanologia Napoli.

Copyright 1988 by the American Geophysical Union.

Paper number 8L6790.

0094-8276/88/008L-6790\$03.00

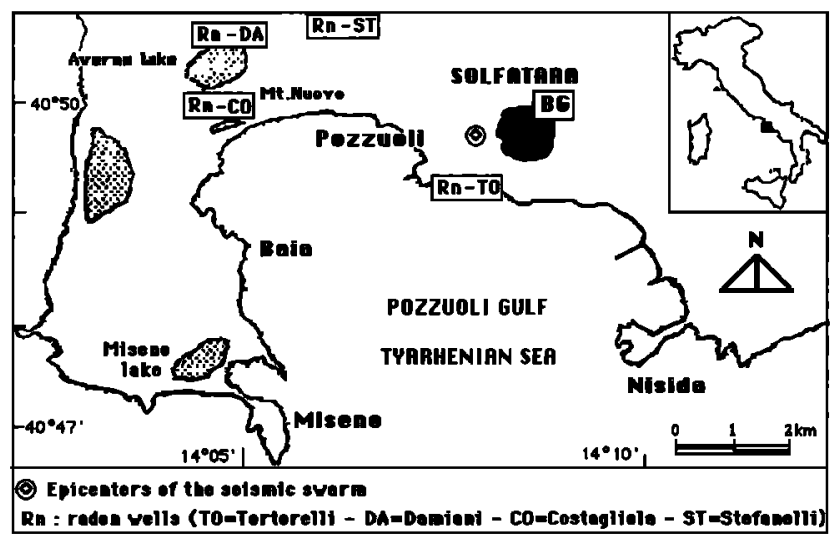

Fig. 1. Map showing Campi Flegrei caldera and harbor. In this figure, all measurement points are located. The 4 wells Costagliola, Damiani, Stefanelli and Tortorelli- where radon is measured, and the Solfatara crater, where fumarolic fluids from Bocca Grande fumarole are sampled, are shown.

the same time, routine geochemical sampling of fumarolic fluids in the Solfatara crater and radon activity in nearby water wells were carried out so that it is possible to determine whether any relationship exists between geochemical and geophysical parameters, such as has been previously observed in other volcanic areas [Khikrkov, 1975; Wakata et al., 1980; Cox et al., 1980; Notsu et al., 1983].

\section{Sampling.}

For fumaroles in Solfatara crater we used pre-evacuated bottles filled with 4N NaOH [Giggenbach, 1975; Tedesco and Sabroux, 1987] to saple the gas. In this manner, atmospheric contamination, although not completely avoided, can be reduced. From the fumarolic vent to the flask we used two quartz dewar tubes [Tedesco and Sabroux, 1987]. This type of sampling permits enrichment of the gas species several hundreds of times, making possible the easy analysis of trace species, such as carbon monoxide, which can be useful for thermodynamic calculations. For isotopic analysis we used pre-evacuated bottles without solution, a technique which also allows very low air contamination.

To analyse the gas composition, a flame ionisation detector (FID) was used downstream from a methanising oven, in series with a $3 \mathrm{~m}$ Porapak $R$ column at room temperature (for analysing $\mathrm{CO}$ and $\mathrm{CH}_{4}$ ). The other gas species were analysed with a thermal conductivity detector downstream from a $3 \mathrm{~m}$ molecular sieve column, either at $65^{\circ} \mathrm{C}$ with helium as a carrier gas (for analysing $\mathrm{O}_{2}+\mathrm{Ar}, \mathrm{N}_{2}$, and $\mathrm{CH}_{4}$ ), or at ambient temperature with argon as a carrier gas (for analysing $\mathrm{He}$ and $\mathrm{H}_{2}$ ). After determining the volume ratio between the liquid phase and the gas phase in the sampling bottle, the $\mathrm{CO}_{3}^{--}$and $\mathrm{S}^{--}$ions in the alkaline solution were analysed by the conventional methods of neutralization by the $\mathrm{HCl}$ and titration by the $\mathrm{Pb}\left(\mathrm{ClO}_{4}\right)_{2}$, using a $\mathrm{pH}$ electrode and sulphide ion specific electrode. $\mathrm{HCl}$ and $\mathrm{HF}$ were also analysed by taccussel ions specific electrodes. The mass of water vapour could then be determined as the difference between the total mass of fluid and the mass of the so called dry gases.

To measure radon content in water wells we used the track-etch method. Alpha-particle sensitive films [Fleischer 


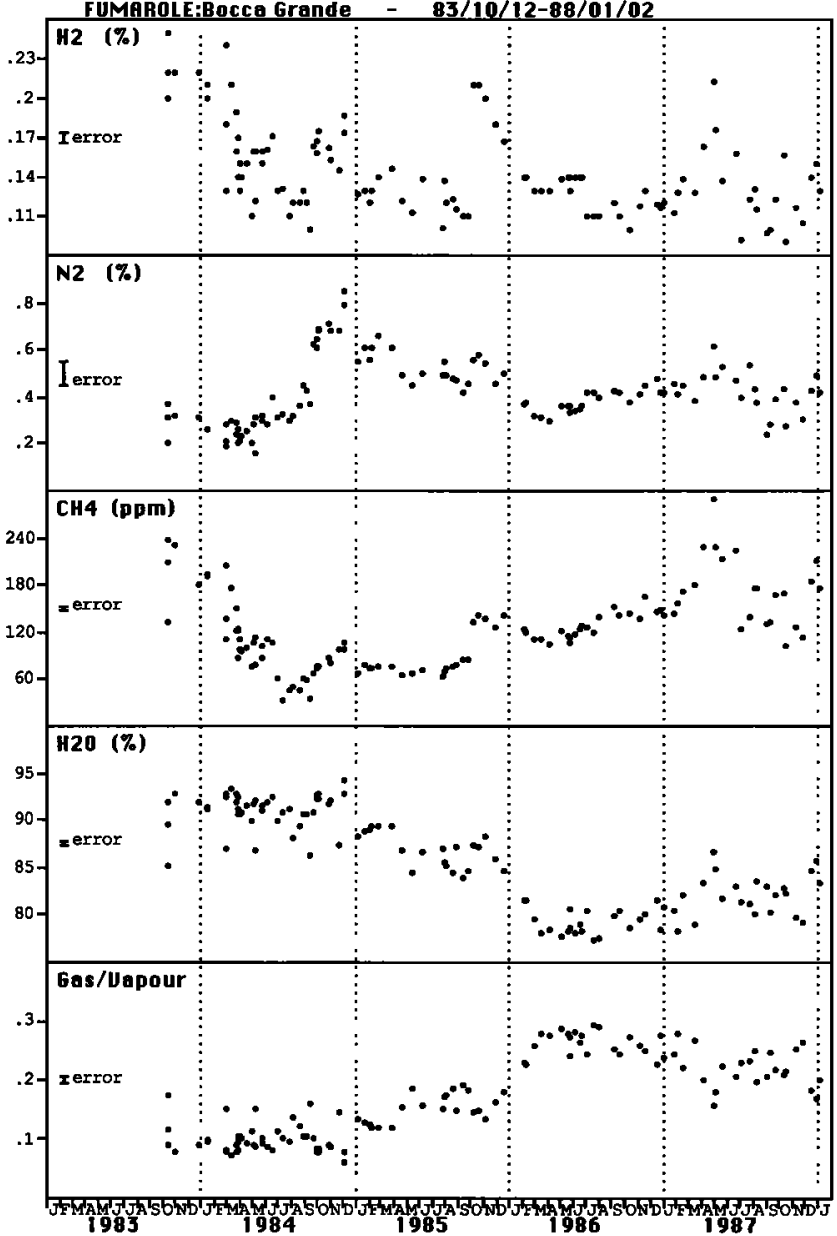

Fig. 2. Correlation between the swarm of the $10^{\text {th }}$ of April and the variations in concentration of $\mathrm{N}_{2}, \mathrm{H}_{2}, \mathrm{CH}_{4}, \mathrm{H}_{2} \mathrm{O}$ and gas/vapour ratio, from Bocca Grande fumarole, Solfatara crater. Variations start for all species sometime before the swarm, reaching their maximum a few days after the seismic activity. Arrows indicate swarms activity during the bradyseismic crisis $\left(13^{\text {th }}\right.$ of October 1988, $1^{\text {st }}$ of April 1984 and $10^{\text {th }}$ of April 1987).

and Mogro-Campero, 1978; Pece and Tedesco, 1986 and Bottiglieri et al., 1987] were fixed on the top of a brass cylinder opened at its lower extremity, permitting gas to flow in. These were seated at the bottom of water wells.

This method is typically used in wells because water collects radon from the rocks it has passed through, and it gives information not only about the measurement point but also for a wide area permeated by water.

The time interval between two measurements was about 10-15 days for cold wells (Costagliola and Stefanelli) and about 7 days for hot wells (Damiani and Tortorelli). The well temperature was measured at the same time as the changing of the sensitive films.

\section{Discussion of results}

Fumarolic gas samples were collected one week before and about two weeks after the earthquake swarm. Variations in concentration of water vapour, nitrogen, hydrogen, methane content and the gas/vapour ratio (Figure 2) were significantly different during this period than the usual seasonal oscillations monitored in these fluids [Tedesco, 1987; Tedesco et al., 1987].
At around the same time, in all wells in which radon was measured, very unusual radon activity was detected (Figures 3 and 4). Of course, the frequency of sampling (for both gas and Rn) has a great influence on the possibility of detecting any variations in the chemical parameters. As we can see here (Figure 2) the recorded variations of chemical species are larger after the seismic swarm. There are two possible reasons: either we stopped the sampling just before the seismic activity when the variations were probably maximal, or, after the seismic activity fumarolic conduit are more open and can easily cause fluids to move towards the surface.

Concerning fumarolic fluids, several variations occurred before the end of the bradyseismic crisis: decreasing hydrogen sulfide $(2.0 \%$ to $0.5 \%)$, hydrogen $(0.20 \%$ to $0.12 \%)$, methane (230 ppm to $50 \mathrm{ppm})$ and $S / C$ ratio and increasing nitrogen $(0.2 \%$ to $0.95 \%)$ and gas/vapour ratio [Tedesco, 1987; Tedesco et al., 1988; Tedesco et al., 1988]. At the same time, during the bradyseismic crisis the temperature monitored at the Bocca Grande fumarole remained constant between $156^{\circ}-160^{\circ} \mathrm{C}$ (continuous monitoring, every 5 minutes). Also, before the crisis, some authors reported an increase in hydrogen sulfide, methane and water vapour contents and S/C ratio [Cioni et al., 1983; Cioni et al., 1984; Martini, 1986].

Following these variations, during the bradyseismic crisis, we paid particular attention to the comparison of
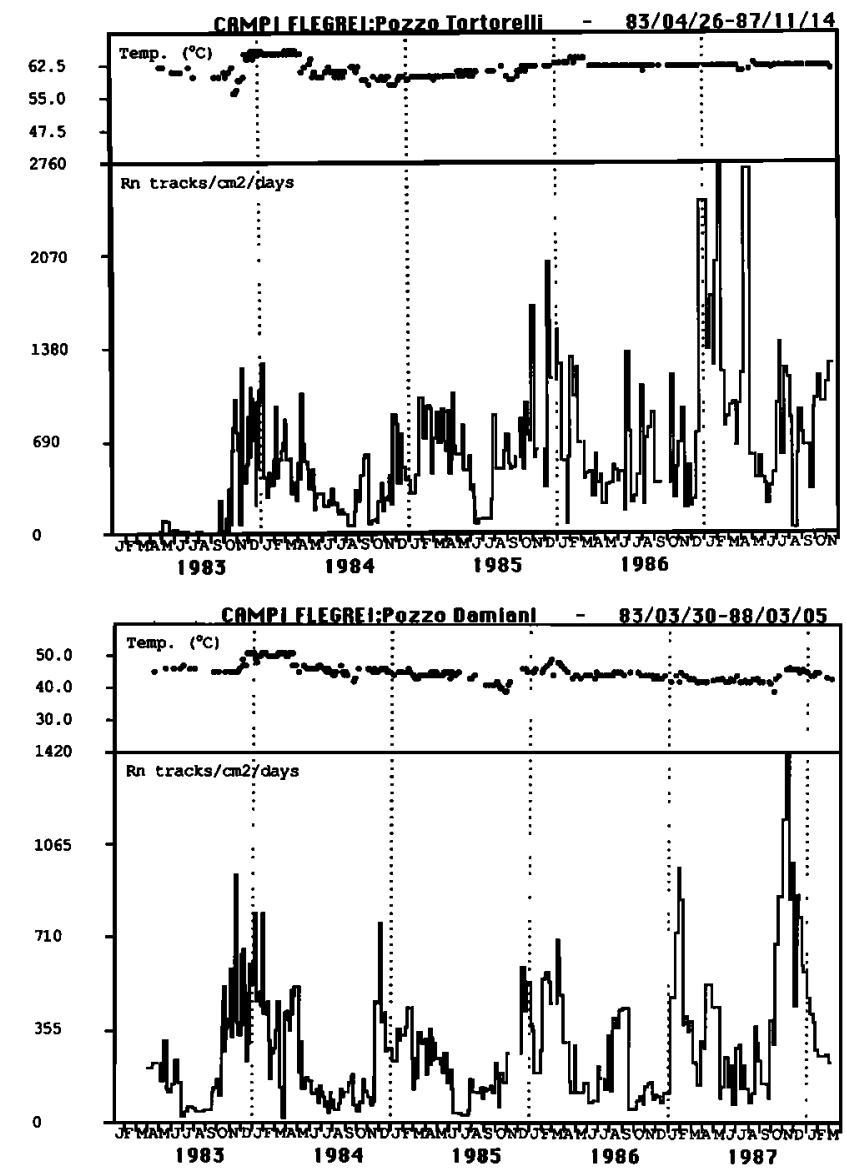

Fig. 3. Radon activity measured by Track-etch method in the two hot wells -Damiani and Tortorelli- correlated with previous earthquahes swarms occurred in the caldera during the bradyseismic crisis (arrows). Radon activity is strongly dependent on water table temperature. The two hot wells give very high $R n$ activity, and the cold wells a very low $R n$ activity (about 20 times less). It is also possible to recognize a seasonal variation (through autumn-winter period) due to rainfall and to the recharge of the acquifers, that affects the radon content in wells and the fluid content of the fumaroles. 

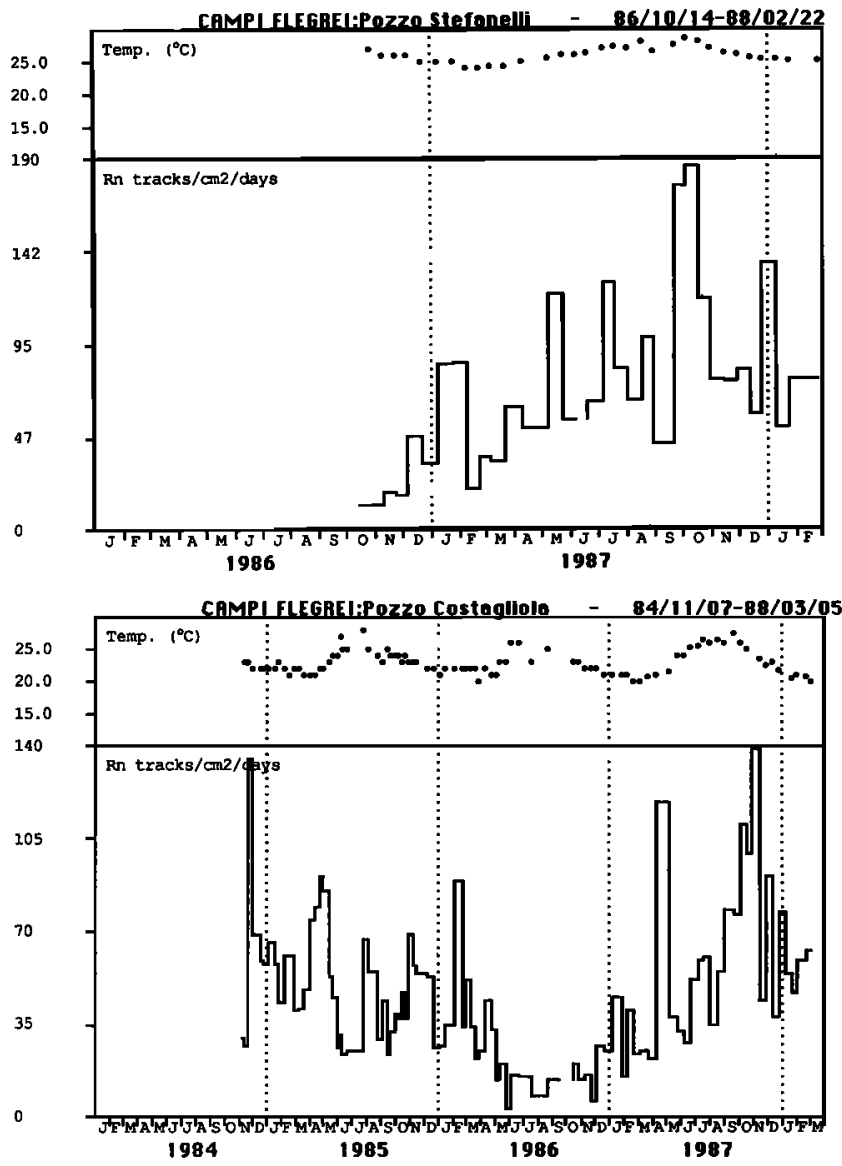

Fig. 4. Radon activity measured by Track-etch method in the cold wells (Costagliola and Stefanelli) plotted with the seismic swarm of the $10^{\text {th }}$ of April (arrow).

geophysical activity (mainly seismicity) and geochemical activity (fumarolic fluid content and radon activity); however the rate of occurrence of earthquakes was so high at that time that no clear correlation was found. After the variations started in March 1984 (seismicity and ground deformations both stopped in January 1985) [Luongo and Ricciardi, 1987], geochemical parameters probably reached a new equilibrium in concentration (Figure 2), possibly indicating a change in thermodynamic conditions in the superficial reservoir feeding the fumaroles of the Solfatara crater. This is indicated by a decrease in the calculated equilibrium temperature from $250^{\circ} \pm 20^{\circ} \mathrm{C}$ to $220^{\circ} \pm 20^{\circ} \mathrm{C}$ after these concentration variations.

The geochemical variations detected at the same time as the seismic activity appear to be the only parameters geophysical or otherwise) that can be correlated with the swarm activity.

The wells sampled for radon measurements consist of two hot wells, Tortorelli and Damiani, whose temperatures are $60^{\circ} \mathrm{C}$ and $45^{\circ} \mathrm{C}$ respectively, and two cold wells, Costagliola and Stefanelli whose temperatures are about $25^{\circ} \mathrm{C}$. The variations do not occur at the same time for all wells. In fact, the radon variations were detected in the two hot wells in April (at the same time as variations in fluids composition) when the swarm occurred, while they are detected with a delay of 15 days to one month, in May, for the cold wells (Figures 3 and 4).

\section{Conclusion}

The volcanic system of Campi Flegrei yields evidence for a strong correlation between geophysical and geochemical activity detected through a correlation between geochemical variations in fumarolic fluids and radon activity related to the seismic swarm. Fumaroles and thermal waters, seem to be the first places where it is possible to record such information at the surface. In our opinion, they are likely to be connected with deeper reservoirs by important (regional) fractures or convective systems where fluids, once injected, quickly arrive at the superficial thermal reservoir. The geographical distribution of wells and their behaviour following the temporal radon injections are important to understand the probable distribution of the superficial thermal system in the caldera; the hot wells, one close (Tortorelli) and one far (Damiani) from the epicentral area, probably belong to the same thermal reservoir. In fact, the increase of radon activity occurred in these two wells simultaneously. For the two cold wells, Costagliola and Stefanelli, both situated far from the epicentral area, the amount of radon content is probably diluted by other water reservoirs before it arrives at the wells where it is monitored, in this case for Stefanelli well one month later. This explains why the hydrothermal system of the Campi Flegrei caldera is, as A.G.I.P. found for deeper reservoirs [A.G.I.P., 1987] in some geothermal wells, constituted of superposed water tables, probably hotter in the middle part of the caldera and colder at the periphery. In any event, this is the first time that a geophysical event (in this particular case, an eathquake swarm) has been detected with several geochemical anomalies in so many places in the Campi Flegrei caldera. This leads us to believe that any new phase of bradyseismic crisis will probably be preceded by a detectable change in geochemical parameters, such as methane, hydrogen, nitrogen and water vapour, which seem to need a very low variation of energy input (enthalpy) into the system to cross the water table reservoir and to reach the surface. The mechanism producing this seismic event, is probably preceded by aseismic creeping that surely enables the migration of fluids before the seismic swarm. In fact, there is no information about seismic mechanisms (such as C.L.V.D.) during the swarm activity in which there is an opening of fractures permitting the escape of fluids. This leads us to believe "creeping" will allow the easy rise of fluids towards the surface.

Acknowledgements. This work has been supported by the Osservatorio Vesuviano and the C.F.R. (CEA-CNRS). A very special thanks to JoAnne for her infinite patience. This is a Centre des Faibles Radioactivités contribution number 953.

\section{References}

A.G.I.P.,: Phlegraean Fields. C.N.R., in Quaderni della ricerca scientifica. Vol. $9^{\circ}$ edited by M. Rosi and $A$. Sbrana,1987.

Barberi, F., Corrado G., Innocenti F. and Luongo G., Phlegraean Fields 1982-84: brief chronicle of a volcano emergency in a densely populated area. Bull. Volcanol. 47. 175-185, 1984.

Bottiglieri, L., Condorelli D., Pece R., Tedesco D., Misure di Radon in aree vulcaniche italiane (Campi Flegrei, Vesuvio, Etna, Vulcano). Bollettino GNV, 159-167, 1987.

Cox, M.E., Cuff K.E. and Thomas D.M., Variations of ground radon concentration with activity of Kilauea volcano, Hawaii. Nature, 288, 74-76, 1980.

Cioni, R., Corazza E. and Marini L., The gas/steam ratio as indicator of heat transfer at the Solfatara fumaroles, Phlegraean Fields. Bull. Volcanol. 47, 295-302, 1984.

Fleischer, R.L. and Mogro-Campero A., Mapping of integrated radon emanation for detection of long-distance migration of gases within the earth: tecniques and principles. J. Geophis. Res, vol. 83, B7, 3539-3549, 1978.

Giggenbach, W., A simple method for the collection and analysis of volcanic gas samples. Bull. Volcanol. 39, 132$145,1975$. 
Khirkov, A.M., Radon as a possible criterion for predecting eruptions as observed at Karamsky volcano. Bull. Volcanol., 37,126-131, 1975.

Luongo, G. and Ricciardi G., Recente attivita sismica ai Campi Flegrei: lo sciame del 10 Aprile 1987. Bollettino G.N.V., 429-436, 1987.

Martini, M., Thermal activity and ground deformation at Phlegraean Fields, Italy: Precursors of eruptions or fluctuactions of quiescent volcanism? A contribution of geochemical studies. J. Geophis. Res. 91, B12, 12.255$12.260,1986$.

Notsu, K,., Abiko T., Wakita H., Radon concentration changes in ground water related to the volcanic activity of Usu volcano. Bull. Volcanol. Soc. Japan. 28, 3, 305$308,1983$.

Pece, R. and Tedesco D., Variazioni del gas Radon in pozzi termalizzati nei Campi Flegrei. Bollettino GNV. 441-447, 1986.

Rosi, M., Sbrana A. and Principe C., The Phlegraean Field: structural evolution, volcanological hystory and eruptive mechanisms. J. Volcanol. Geoth. Res., 17, 273-288, 1983.

Tedesco, D. and Sabroux J.C., The determination of deep temperatures by means of the $\mathrm{CO}-\mathrm{CO}_{2}-\mathrm{H}_{2}-\mathrm{H}_{2} \mathrm{O}$ geothermometer: an example using fumaroles in the Campi
Flegrei, Italy. Bull of Volcand $1,49,381-387,1987$.

Tedesco, D., Significato ed elaborazione termodinamica dei fluidi di ambienti idrotermali (Campi Flegiei e Long Valley) e vulcanici (Hawaii e Mt. Usu), thesis, $252 \mathrm{pp}$, Uhivetsity of Naples, Italy, September 1, 1987.

Tedesco, D., Allard P.; Sabroux J.C and Pece R. Geochernical response of voleanic gases to bradyselsmic

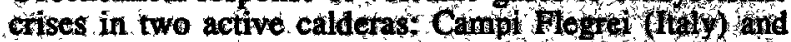
Long Valley (U.S.A.). A conparative study, In oress 61 . Geophys. Res.

Wakita, H., Nakamura Y., Notsu K., Noguchi M. and Asada T., Radon anomaly: a possible precursot of the 1978 IzuOshima-kinkai earthquake. Science, 207, 882-883, 1980.

D. Tedesco, Centre des Faibles Radioactivités, CNRSCEA, 91198 Gif sur Yvette, France.

D.Tedesco and L. Bottiglieri, Osservatorio Vesuviano, Via Manzoni 249, 80123 Napoli, Italia.

R. Pece, Dipartimento di Geofisica e Vulcanologia, Largo S. Marcellino, 80138 Napoli, Italia.

(Received: March 11, 1988; Accepted: May 5, 1988.) 